Annals of Warsaw University of Life Sciences - SGGW

Land Reclamation No 48 (3), 2016: 233-242

(Ann. Warsaw Univ. of Life Sci. - SGGW, Land Reclam. 48 (3), 2016)

\title{
Estimating and verifying soil unit weight determined on the basis of SCPTu tests
}

\author{
IRENA BAGIŃSKA \\ Institute of Geotechnology and Hydrology, Below-ground Water Constructions, \\ Wrocław University of Science and Technology, Poland
}

\begin{abstract}
Estimating and verifying soil unit weight determined on the basis of SCPTu tests. The unit weight, as a basic physical feature of soil, is an elementary quantity, and knowledge of this parameter is necessary in each geotechnical and geo-engineering task. Estimation of this quantity can be made with both laboratory and field techniques. The paper comprises a multi-scale evaluation of unit weight of cohesive soil, based on several measurements made in nearby locations using the SCPTu static probe. The procedures used were based on the two classifications and two solutions from literature. The results were referenced to the actual values of unit weight determined with a direct procedure from undisturbed samples. The resulting solutions were the basis for proposing a new formula to determine the soil unit weight from SCPTu measurements, as well as comparative analysis using exemplary values taken from the national Polish standard.
\end{abstract}

Key words: soil unit weight, piezocone penetration test $(\mathrm{CPTu})$, seismic cone penetration testing (SCPTu)

\section{INTRODUCTION}

The CPTu static probing is a common research technique applied in identifying a soil sub-base in situ. Additional expanding it by a seismic module (SCPTu) increases its cognitive capabilities for both physical and mechanical characteristics of the tested soil profile. The study analyses the possibilities of using the aforementioned research techniques in indirect determination of basic physical feature of soil, which is the unit weight. Knowledge of this parameter is necessary in calculating overburden stresses in the soil $\left(\sigma_{\vartheta 0}, \sigma_{\vartheta 0}^{\prime}\right)$, normalized interpretation values (e.g. $Q_{t}, F_{r}, B_{q}$ ) as well as other values describing the condition and deformability of soil (e.g. $I_{D}, G_{o}, v, s_{u}$ ) correlated with $\mathrm{CPTu} / \mathrm{SCPTu}$ measurement quantities, i.e. the cone resistance $\left(q_{c}\right)$, sleeve friction $\left(f_{s}\right)$ and pressure rise $\left(u_{2}\right)$.

The unit weight values can be obtained by direct method from undisturbed samples or indirectly from correlations based on the $\mathrm{CPTu} / \mathrm{SCPTu}$ measurement. The first method is based on drilling and collecting samples, individually for each layer in the profile, however it is a complicated, time-consuming and costly process. Therefore, the interpreters usually use ready-made interpretation correlations which determine the unit weight on the basis of values measured in situ from probings $\left(q_{c}, f_{s}\right.$ and $\left.u_{2}\right)$. Values obtained in this way in further interpretation analyses are repeatedly applied in subsequent interpretation equations used for determining various features. The unit weight adopted improperly in the first steps of the interpretation may affect parameters determined indirectly, e.g. deformability and strength of soil. 
In this study several procedures were used for determining the unit weight on the basis of CPTu/SCPTu tests (Lunne et al. 1987, Mayne 2007, Robertson and Cabal 2010, Mayne 2014). When selecting computational formulas the focus was on applying them for cohesive soils. The results were referenced to actual values of unit weight determined by direct procedure from undisturbed samples.

Attempts to verify the actual unit weight measurements in relation to solutions described in literature were previously conducted in Poland by Młynarek (2013). However, they concerned only coarse-grained soils, therefore - in the author's opinion - it is important to try to investigate whether and how the literature correlations perform locally in evaluation of fine-grained soil.

\section{Selected methods for determining soil unit weight}

The first proposal for determining the unit weight on the basis of CPT probings

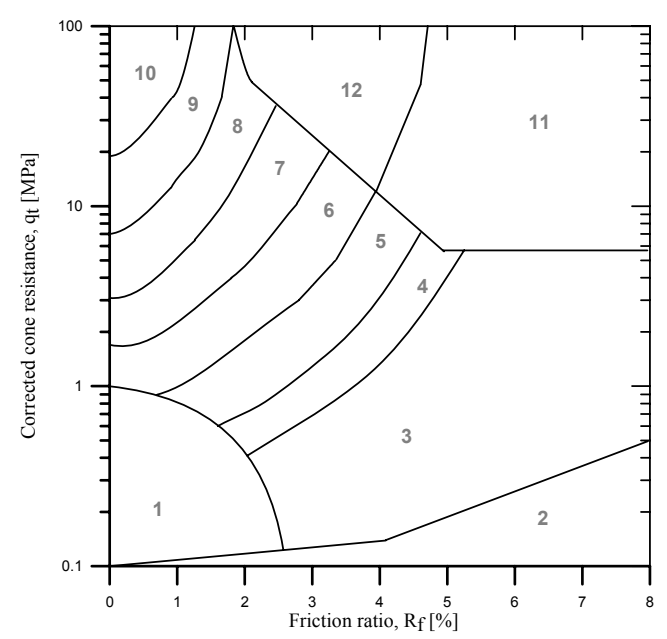

FIGURE 1. Classification nomograph proposed by Robertson et al. (1986) was presented by Lunne et al. (1997) (Fig. 1). The authors suggested, based on SBT zones in the classification of Robertson et al. (1986) (Fig. 1), the deterministic relationship of individual SBT zones with specific values of soil unit weight. In other words, for a particular type of soil, regardless of its condition, a specific value of unit weight was assigned (Fig. 2).

In subsequent publication Robertson and Cabal (2010) updated the procedure for determining unit weight on the basis of classification nomograph proposed by Robertson et al. (1986) - Figure 3. Within a specific SBT zone, i.e. one type of soil, it became possible to obtain different soil unit weights. The values of unit weight grow within each SBT zone with increasing values of $q_{t}$ and $R_{f}$, and their dispersion from average value for a particular SBT amounts to about $20 \%$.

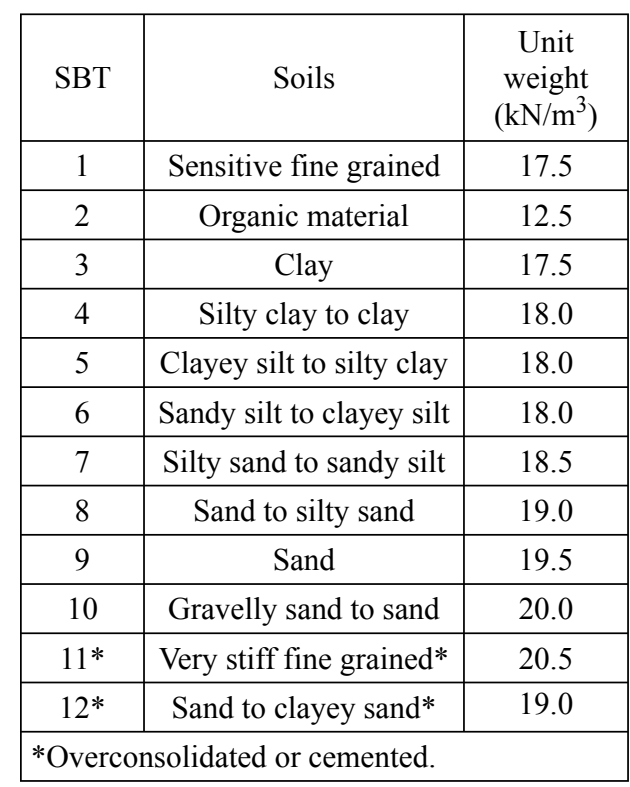

FIGURE 2. Specification of SBT zones with assigned soil unit weights 


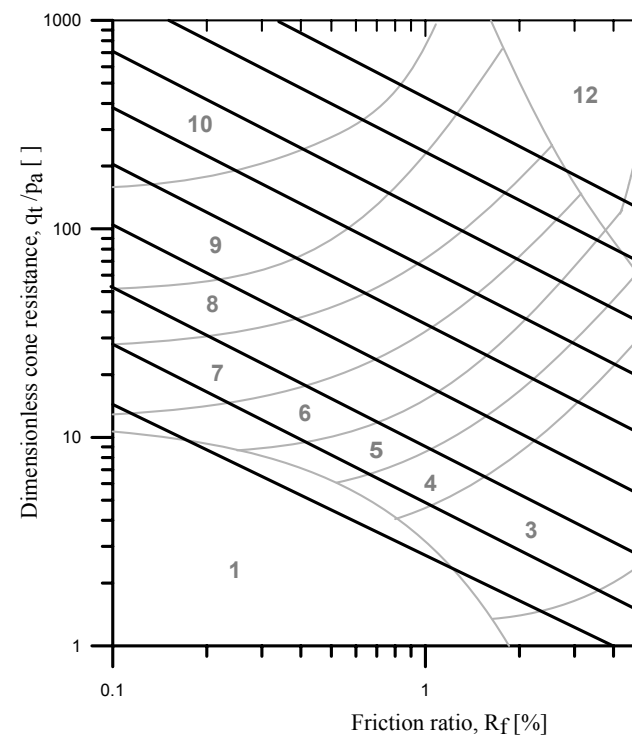

FIGURE 3. Classification nomograph and soil unit weight by Robertson and Cabal (2010)

In parallel with the graphic solution Robertson and Cabal (2010) proposed a correlation which allows one to calculate the unit weight on the basis of equation (1).

$$
\frac{\gamma}{\gamma_{w}}=0.27\left[\log R_{f}\right]+0.36\left[\log \left(\frac{q_{t}}{p_{a}}\right)\right]+1.236
$$

where:

$R_{f}=\left(f_{s} / q_{t}\right) 100 \%$ - friction ratio;

$\gamma_{w}-$ unit weight of water in same units as $\gamma$;

$p_{a}-$ atmospheric pressure in same units as $q_{t}$.

A different methodology for evaluating the unit weight using CPTu static probing was proposed by Mayne (2014). The derived formulas were created on the basis of a large number of diverse samples of soil, from coarse-grained to finegrained ones (Fig. 4). The unit weight variability was dependent on the value of sleeve friction $-f_{s}$, measured during the CPTu test, using equations (2) and (3).

$$
\gamma_{t}=26-\frac{14}{1+\left[0,5 \cdot \log \left(f_{s}+1\right)\right]^{2}}
$$

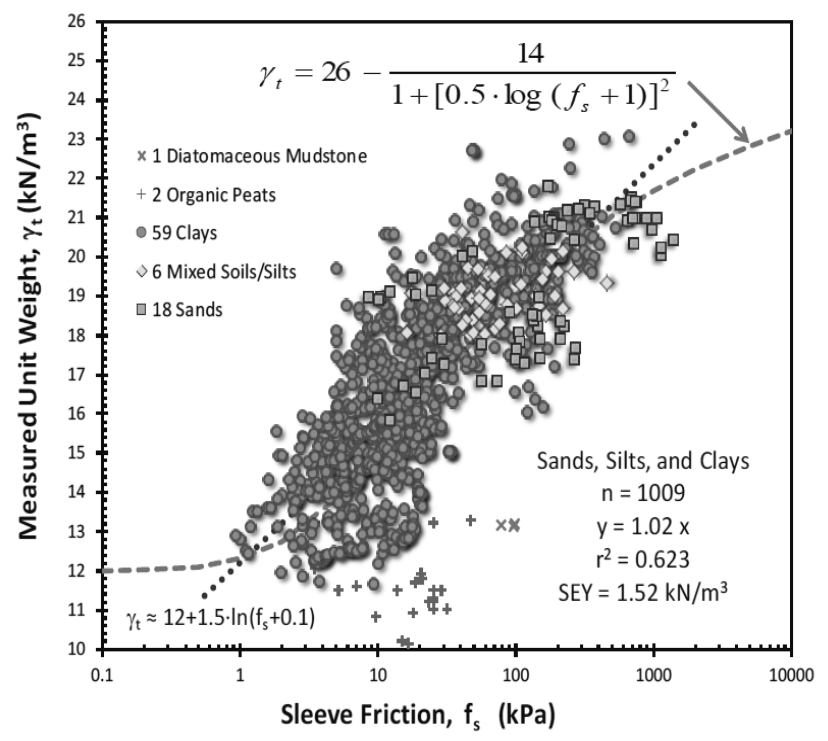

FIGURE 4. Unit weight variability depending on sleeve friction (Mayne 2014) 
$\gamma_{t}=12+1.5 \cdot \ln \left(f_{s}+0.1\right)$

In addition, Mayne (2007) also proposed a different formula based on the seismic recognition, e.g. SCPTu, which during the classical measurement with a piezocone also allows one to determine the shear wave velocity in the soil. In this case also, the basis for the formulation of equation (4) were test results from a large group of soils, both coarse-grained and fine-grained ones (Fig. 5).

$\gamma_{t}=8.32 \cdot \log \left(V_{S}\right)-1.61 \log (z)$

where:

$V_{s}$ - shear wave velocity $(\mathrm{m} / \mathrm{s})$; $z$-depth (m).
The four literature methods applicable for evaluating soil unit weight may be used for all types of soils. In the study they were referenced to the actual research on cohesive soil from the southwestern region of Poland.

\section{Measurement data from the research zone}

In order to evaluate the unit weight - six static probings were made with seismic module (SCPTu) and three CPTu static probings. For verification purposes eight samples of undisturbed soil were taken from boreholes using a plunge sampler. In the laboratory the samples were sub-

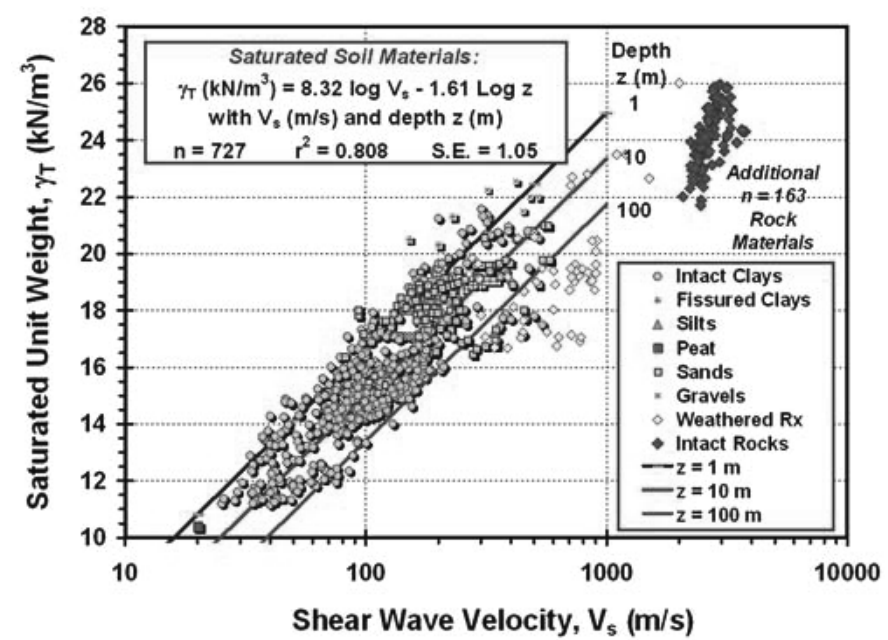

FIGURE 5. The unit weight variability at shear wave velocity (Mayne 2007)

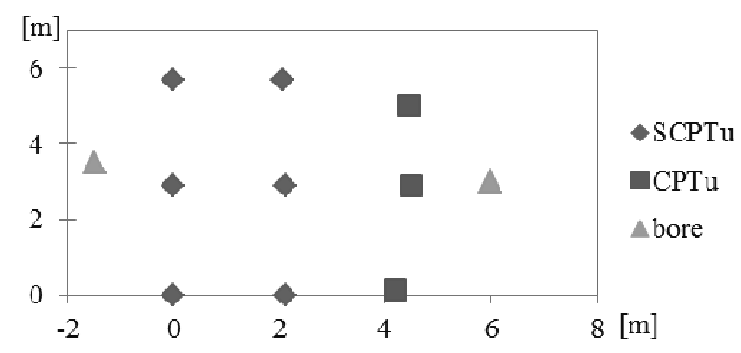

FIGURE 6. Distribution of exploratory boreholes 
ject to the estimation of their unit weight, analysis of natural moisture and evaluation of grain composition. Distribution of research points was in line with Figure 6. The minimum spacing between $\mathrm{SCPTu} /$ $/ \mathrm{CPTu}$ boreholes was $2.1 \mathrm{~m}$, and the maximum spacing about $3 \mathrm{~m}$.

Making the nine static tests (SCPTu + $+\mathrm{CPTu}$ ) made it possible to obtain the average of the received measurements and more precisely separate the zones with similar soil characteristics. The calculated average measured values $\left(q_{c}\right.$, $f_{s}$ ) were the basis for calculating the soil unit weight using methods mentioned in the literature. Figures 7 and 8 presents the course of recorded values of the cone resistance $\left(q_{c}\right)$, sleeve friction $\left(f_{s}\right)$ and the distribution of measurement points on the classification nomograph of Robertson et al. (1986) with division into individual depth layers.

For further analysis the layer of finegrained soil was selected between 4 and $8 \mathrm{~m}$ below ground level. With the use of the nomograph proposed by Robertson et al. (1986) the soil was mostly classified as SBT 4 (silty clay to clay) and to a limited extent as SBT 3 (clay), SBT 5 (clayey silt to silty clay) - Figures 2 and 7 .

Additionally, thanks to the seismic module equipped with accelerometers, accelerations of soil vibrations induced on the ground surface were recorded at various depths (Fig. 9). The measurement and interpretation of performed tests were carried out according to the technique described in the work of Bagińska et al. (2013). Recordings from particular neighbouring depths were "overlapped" onto each other, thus obtaining time differences in the arrival of shear waves. The shear wave velocity was calculated as a quotient of difference in the measuring module depression depth to the difference in time of transverse wave arrival at both depths.

As a result of the grain size analysis performed in the laboratory on eight samples taken from depths (4 to $8 \mathrm{~m}$ )

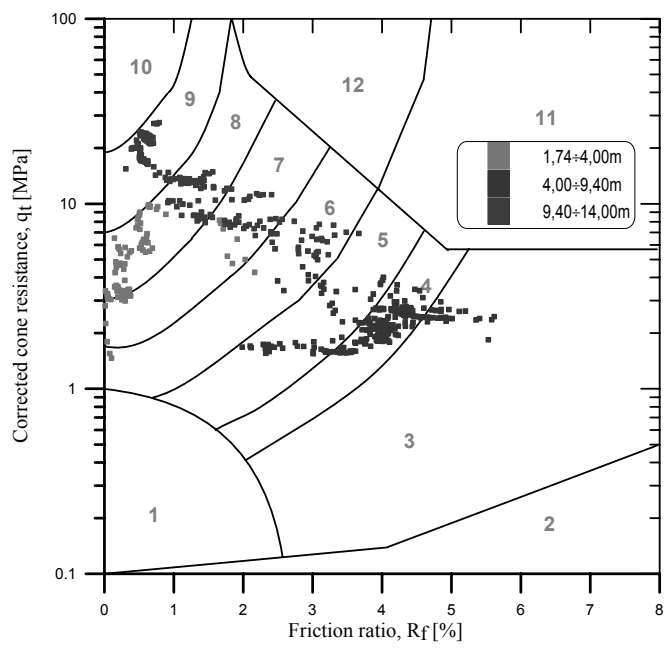

FIGURE 7. Soil classification nomograph by Robertson et al. (1986) 

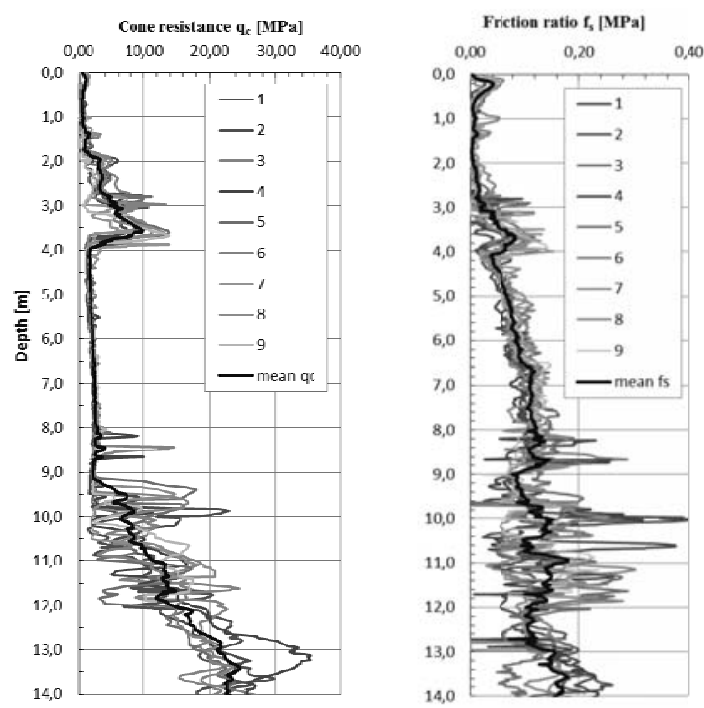

FIGURE 8. Depth-dependent graph of recorded and averaged measurement values of $q_{c}$ and $f_{s}$ from $\mathrm{SCPTu}+\mathrm{CPTu}$ tests

a

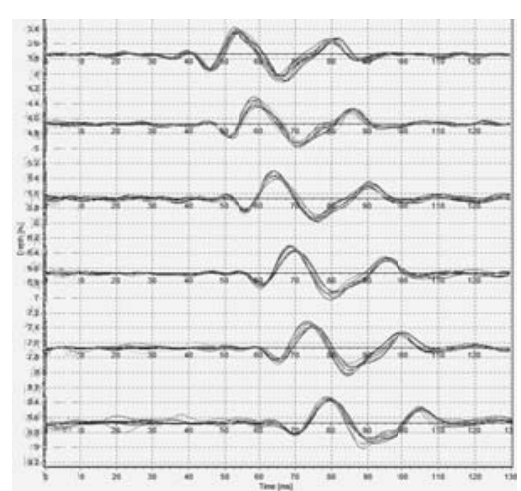

b

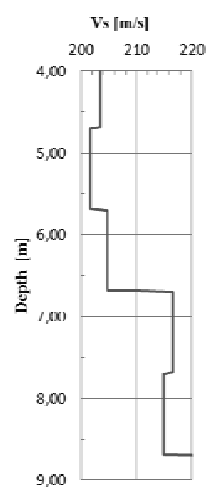

$\mathrm{c}$

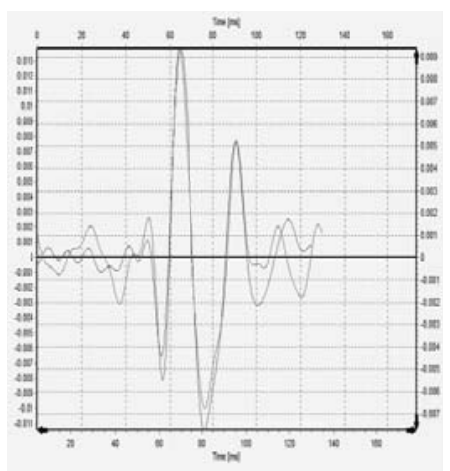

FIGURE 9. The results of seismic research: (a) Recorded shear wave activation at various depths; (b) shear wave velocity interpretation result; (c) example "overlap" of recordings from two different depths

of the analysed layer it was shown, that $22.02 \mathrm{kN} / \mathrm{m}^{3}$ with a standard deviation the studied soil, according to PN-EN ISO of 0.39 , and the average natural moisture 14688-2:2006, was classified as a sandy determined according to PKN-EN ISO silty clay (sasiCl). Its average unit weight 17892-1:2015-02 amounts to $9.69 \%$ with determined in accordance with PKN- a standard deviation equal to 0.75 . EN ISO 17892-2:2015-02 amounts to 


\section{ANALYSIS OF TEST RESULTS AND THEIR VALIDATION}

The first stage in the analysis of the test results was to reference the received actual unit weights of natural soil to estimated values of unit weights for similar soils from the national standard PN-81/B-03020 (Fig. 10). Results depending on the natural humidity proved to be very similar in terms of the considered natural humidity. tained in relation to the depth. The next step was to use the equations (1), (2), (3), (4) and calculate the unit weight analytically in accordance with guidelines of each method.

Results of the unit weight evaluation obtained by literature methods along with actual values are presented in Figure 12. Unit weight values determined directly from undisturbed samples turned out to be approximately $20 \%$ higher than the values calculated by literature methods,

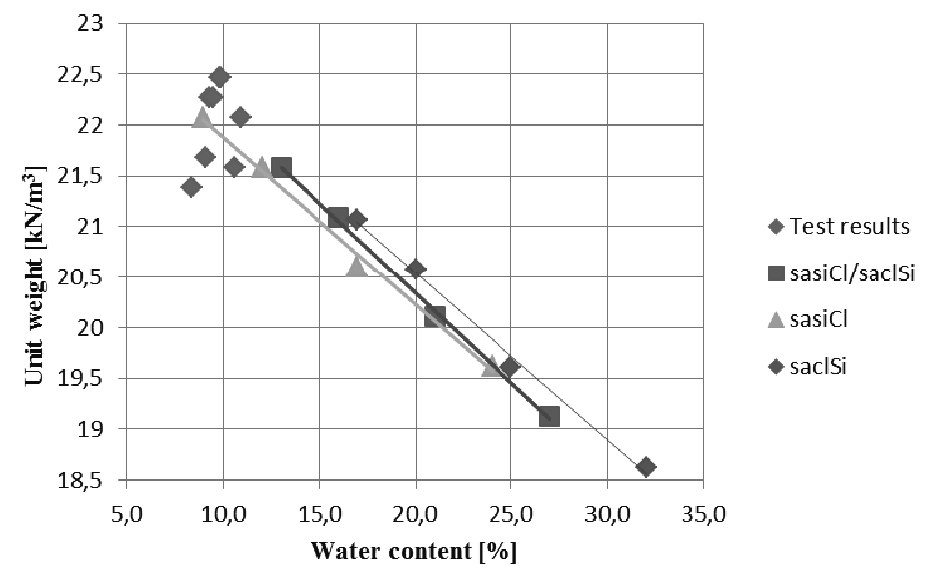

FIGURE 10. Dependence of unit weight on moisture for cohesive soils according to PN-81/B-03020 along with the author's test results

The second stage of the analysis was the verification of the author's soil unit weight results in relation to quantities determined in accordance with literature methods.

On the nomograph of Robertson et al. (1986) (Fig. 7) as well as Robertson and Cabal (2010) measurement points were placed (Fig. 11), obtained from the averaged measured values $q_{c}$ and $f_{s}$ at depths from 4 to $8 \mathrm{~m}$ below ground level. By analysing the position of each of the points in individual SBT zones and $\gamma / \gamma_{w}-$ two unit weight variation graphs were ob- which gave similar results with respect to each other. This may indicate a very close affinity of soils for which the literature methods were established.

To check the dissimilarities in characteristics of the native soil from the area of south-western Poland the author's results were placed on the Mayne charts (Fig. 13).

Graphic illustration in Figures 11 and 12 , presenting the real estimation of unit weight for the cohesive soil being evaluated, allowed one to formulate and propose new correlation equations 


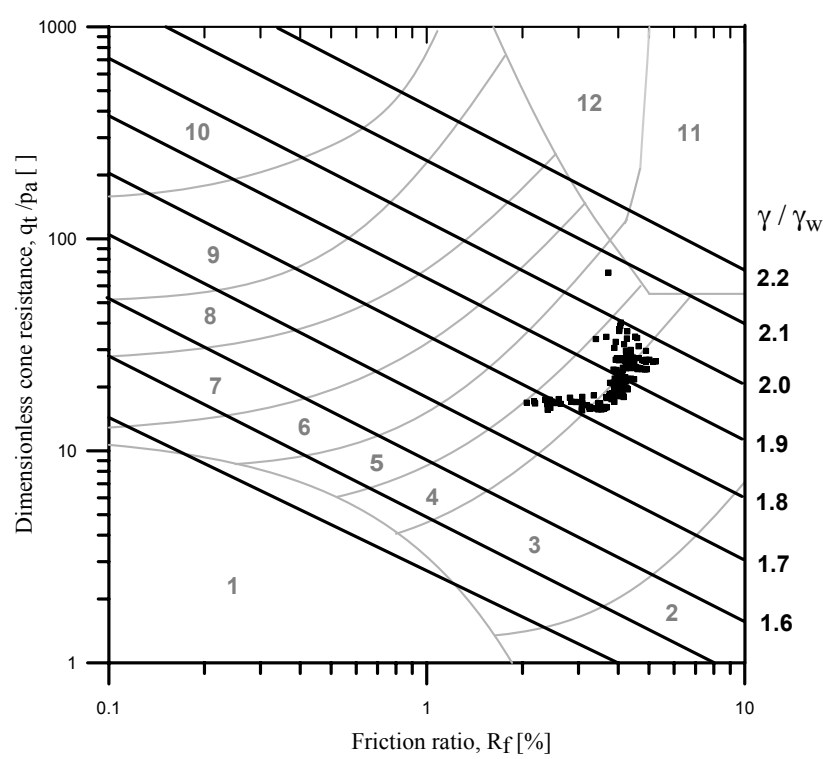

FIGURE 11. Distribution of average measured values from depths between 4 to $8 \mathrm{~m}$ below ground level on the Robertson and Cabal nomograph (2010)

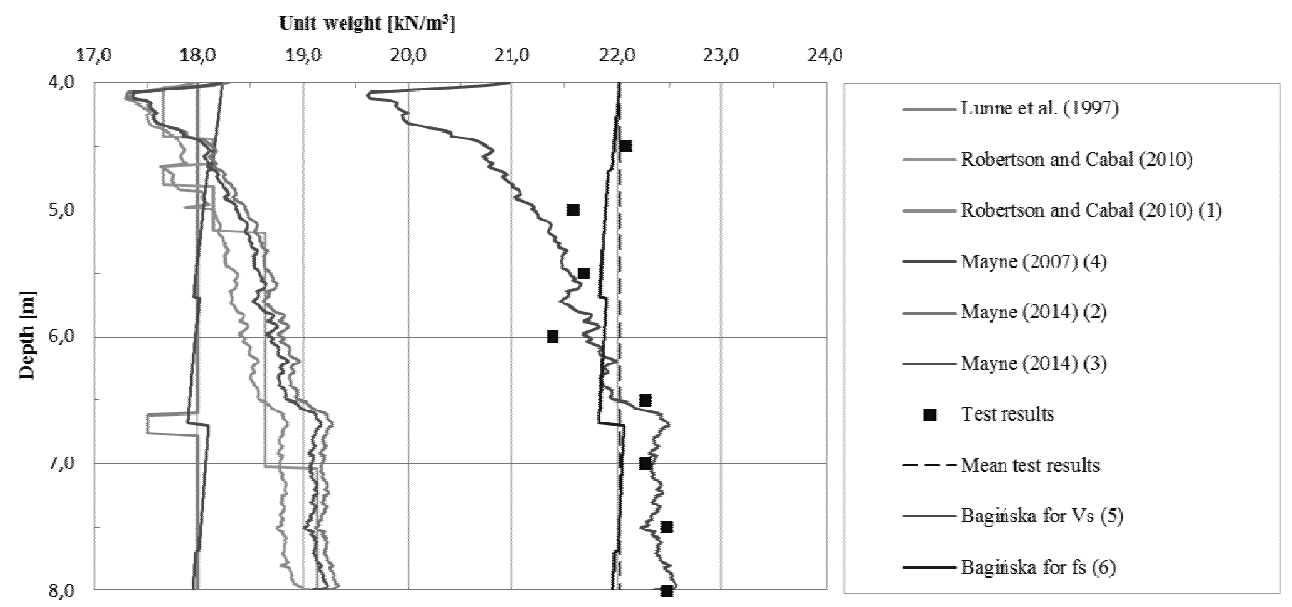

FIGURE 12. Results of the unit weight

best suited to the literature data (Fig. 12) and the actual measurements (Fig. 11). In this way, the validation of proposed solutions was performed both on values determined locally and those established from literature data.
With reference to Mayne (2007) the equation (5) was proposed, while with reference to Mayne (2014) it was the equation (6).

$$
\begin{aligned}
& \gamma_{t}=9.8 \cdot \log \left(V_{S}\right)-\log (z) \\
& \gamma_{t}=11+2.4 \cdot \ln \left(f_{s}+0.7\right)
\end{aligned}
$$



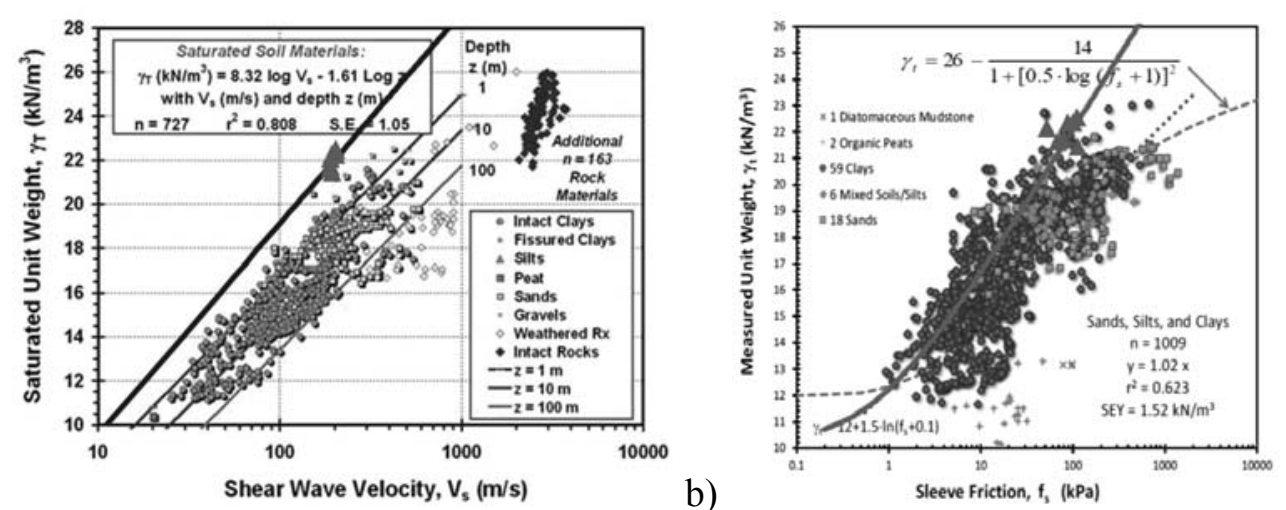

FIGURE 13. The author's results placed on graphs: (a) Mayne (2007); (b) Mayne (2014).

\section{CONCLUSIONS}

1. The soil unit weight is a very important physical parameter indispensable for geotechnical tasks and interpretation process of static probings.

2. Values measured in the CPTu/SCPTu test $\left(q_{c}, f_{s}\right.$ and $\left.u_{2}\right)$ are valuable data for qualitative and quantitative assessment of the soil. One should try to determine as many features as possible directly from the measured values and not from derivatives, so as to avoid multiple error resulting from intermediate correlations which can distort the correctness of interpretations obtained.

3. The application of the seismic module (SCPTu) extends the cognitive capabilities for evaluating the soil features. Introduction of shear wave velocity $\left(V_{s}\right)$ into the analysis provides additional information on the native soil, which allows one to perform multi-scale analysis and interpretation.

4. The determined values of unit weight for sandy silty clay (sasiCl) from the south-western region of Poland, for soil samples of type A (with undisturbed structure), are about $20 \%$ higher than values obtained from literature correlations. This confirms that the literature correlations should be used with caution and limited confidence. Their application should always be preceded by field tests and/or laboratory tests to ensure reliability of results. Particular care should be taken when determining the characteristics in which the value of unit weight is of particular importance for the quantity to be determined. This is especially applicable to, e.g. the dynamic shear modulus - $G_{\max }$ (or $G_{o}$, $\left.M_{o}, M_{\max }\right)$. In such cases, the unit weight should be determined directly or from local correlations. Therefore, there is a justified need to build local (representative) measurement bases in order to create local correlations which may become the basis for interpretations on both fine-grained and coarse-grained soils. 


\section{REFERENCES}

BAGIŃSKA I., JANECKI W., SOBÓTKA M. 2013: On the interpretation of seismic cone penetration test (SCPT) results. Studia Geotechnica et Mechanica 35 (4), 3-11.

LUNNE T., ROBERTSON P.K., POWELL J.J.M. 1997: Cone Penetration Testing in Geotechnical Practice. Blackie Academic/Routledge Publishing, New York.

MAYNE P.W. 2007: In-situ test calibrations for evaluating soil parameters. Characterization \& Engineering Properties of Natural Soils, Vol. 3. Taylor \& Francis Group, London, 1602-1652.

MAYNE P.W. 2014: Interpretation of geoparameters from seismic piesocone tests. 3rd International Symposium on Cone Penetration Testing, Las Vegas.

MŁYNATEK Z. 2013: Session report: Direct push-in in situ test. In: R.Q. Coutinho, P.W. Mayne (Eds). Geotechnical and Geophysical Site Characterization 4. CRC Press, 299-312.

PN-81/B-03020. Posadowienie bezpośrednie budowli. Obliczenia statyczne i projektowanie.

PN-EN ISO 14688-2:2006. Geotechnical investigation and testing - Identification and ckassification of soil - Part 2: Principles for a classification.

PKN-EN ISO 17892-1:2015-02. Geotechnical investigation and testing - Laboratory testing of soil - Part 1: Determination of water content.

PKN-EN ISO 17892-2:2015-02. Geotechnical investigation and testing - Laboratory testing of soil - Part 2: Determination of bulk density.

ROBERTSON P.K., CABAL K.L. 2010: Estimating soil unit weight from CPT. $2^{\text {nd }}$ International Symposium on Cone Penetration Testing CPT ‘ 10 , Vol. 3.
ROBERTSON P.K., CAMPANELLA R., GILLESPIE D., GRIEG J. 1986: Use of piezometr cone data. IN-SITU'86, ASCE Specialty Conference, Blacksburg.

Streszczenie: Ocena i weryfikacja ciężaru objętościowego gruntu wyznaczonego na podstawie badań SCPTu. Ciężar objętościowy, jako podstawowa cecha fizyczna gruntu, jest wielkością elementarną, a jej znajomość jest konieczna w każdym zadaniu geotechnicznym i geoinżynierskim. Do oceny tej wielkości można zastosować zarówno techniki laboratoryjne, jak i polowe. W pracy przeprowadzono wielkoskalową ocenę gęstości objętościowej gruntu spoistego, bazując na kil$\mathrm{ku}$ pomiarach w bliskiej lokalizacji wykonanych sondą statyczną SCPTu. Zastosowano procedury opracowane na podstawie dwóch klasyfikacji oraz dwóch rozwiązaniach literaturowych. Wyniki odniesiono do rzeczywistych wartości ciężaru objętościowego ustalonych procedurą bezpośrednią z prób o nienaruszonej strukturze. Otrzymane rozwiązania były podstawą zaproponowania nowej formuły ustalenia ciężaru objętościowego grunt z pomiarów SCPTu oraz analizy porównawczej z przykładowymi wartościami zaczerpniętymi z krajowej normy polskiej.

MS received June 2016

\section{Author's address:}

Irena Bagińska

Katedra Geotechniki, Hydrotechniki, Budownictwa Podziemnego i Wodnego Wydział Budownictwa Lądowego i Wodnego

Politechnika Wrocławska

Plac Grunwaldzki 11, 50-377 Wrocław

Poland 